\title{
Demonstrating The Use Of Vector Error Correction Models Using Simulated Data
}

Carl B. McGowan, Jr., Norfolk State University, USA

Izani Ibrahim, National University of Malaysia, Malaysia

\begin{abstract}
In this paper, we demonstrate the use of time series analysis, including unit roots tests, Granger causality tests, cointergation tests and vector error correction models. We generate four time series using simulation such that the data has both a random component and a growth trend. The data are analyzed to demonstrate the use of time series analysis procedures.
\end{abstract}

Keywords: Time Series Analysis; Simulation; Unit Root Tests; Granger Causality; Cointegration; Vector Error Correction Models

\section{INTRODUCTION}

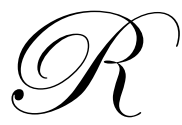

egressions between levels of variables may have high covariation because of persistence in the base levels of the variables rather than persistence in the changes in the values of the variables. Taking the first differences of the variables may eliminate, or at least reduce, the dependence between the variables. Gross national income from period to period is an integrated process, but the changes in GNI are not an integrated process. The first differences of GNI are an independent, identically distributed process which are only weakly dependent. An alternative transformation to differencing is to take the natural logarithm of the ratio of the two levels to generate the percentage rate of change which generates a continuously compounded rate of change.

\section{STATIONARITY AND DICKEY-FULLER}

Ordinary Least Squares regression requires that the time series being evaluated be stationary. Otherwise, OLS is no longer efficient, the standard errors are understated, and the OLS estimates are biased and inconsistent. Stationarity requires that the time series values for the mean, the standard deviation, and the covariance, be invariate over time ${ }^{1}$.

$\mathrm{E}\left(\mu_{\mathrm{t}-1}\right)=\mathrm{E}\left(\mu_{\mathrm{t}}\right)$, i. e., $\mu_{\mathrm{t}}$ is constant over time,

$\mathrm{E}\left(\sigma_{\mathrm{t}-1}\right)=\mathrm{E}\left(\sigma_{\mathrm{t}}\right)$, i. e., $\sigma_{\mathrm{t}}$ is constant over time, and

$\mathrm{E}\left(\operatorname{cov}_{\mathrm{t}-1}\right)=\mathrm{E}\left(\operatorname{cov}_{\mathrm{t}}\right)$, i. e. the covariance of $\left(\mathrm{x}_{\mathrm{t}}, \mathrm{x}_{\mathrm{t}-1}\right)$ is constant over time.

That is, the mean for any time (t-1) will equal the mean for any time ( $\mathrm{t})$, the standard deviation for any time (t-1) will equal the standard deviation for any time $(\mathrm{t})$, and the covariance for any time (t-1) will equal the covariance for any time $(\mathrm{t})$.

One method to test for stationarity is the unit root test of Dickey-Fuller (1979). To test for a unit root of a stochastic time series, the value of the random variable is regressed against lagged values of the same random variable

$\mathrm{x}_{\mathrm{t}}=\alpha+\beta \mathrm{x}_{\mathrm{t}-1}+\varepsilon_{\mathrm{t}}$

\footnotetext{
${ }^{1}$ See Wooldridge (2003) for a more detailed discussion of the theoretical models discussed in this paper. 
where, $x_{t}$ is the value of the time series at time $(t), \alpha$ is the intercept term, $\beta$ is the regression coefficient, $x_{t-1}$ is the lagged value of the time series, and $\varepsilon_{t}$ is the residual. If $\beta$ is equal to one, then the process generating the time series is non-stationary. The null hypothesis is that $\mathrm{H}_{0}: \beta=1$ and the alternative hypothesis is that $\beta$ is less than one, $\mathrm{H}_{1}$ : $\beta<1$. The actual test is run after subtracting $\mathrm{x}_{\mathrm{t}-1}$ from both sides of Equation [1]. The regression is

$\Delta \mathrm{x}_{\mathrm{t}}=\alpha^{*}+\beta^{*} \mathrm{x}_{\mathrm{t}-1}+\varepsilon_{\mathrm{t}}^{*}$

where the $(*)$ indicates the parameters from the regression adjusted by subtracting $\mathrm{x}_{\mathrm{t}-1}$. The null hypothesis is that $\mathrm{H}_{0}: \beta^{*}=0$ and the alternative hypothesis is that $\beta$ is less than zero, $\mathrm{H}_{1}: \beta^{*}<0$.

This model is only valid for AR(1) processes. If the underlying return generating process exhibits serial correlation of order greater than one, Augmented Dickey-Fuller tests must be used. Higher order terms are included in the regression

$\Delta \mathrm{x}_{\mathrm{t}}=\alpha^{*}+\beta^{*} \mathrm{x}_{\mathrm{t}-1}+\beta_{1} \Delta \mathrm{x}_{\mathrm{t}-1}+\beta_{2} \Delta \mathrm{x}_{\mathrm{t}-2}+\ldots .+\beta_{\mathrm{n}} \Delta \mathrm{x}_{\mathrm{t}-\mathrm{n}}+\varepsilon_{\mathrm{t}}^{*}$

where, the additional terms are derived from the higher order $\operatorname{AR}()$ terms. The null hypothesis is that $\mathrm{H}_{0}: \beta^{*}=0$ and the alternative hypothesis is that $\beta^{*}$ is less than one, $\mathrm{H}_{1}: \beta^{*}<0$.

\section{CO-INTEGRATION AND ENGLE-GRANGER}

Co-integrated processes are random in the short-term but tend to move together in the long-term. Wooldridge (2003) shows that six-month Treasury bill rates and three-month Treasury bill rates are both unit root processes that are independent in the short-term but do not drift too far apart in the long-term. If either rate moves too far from equilibrium, either too high or too low, investors move money from the low (high) rate alternative to the high (low) rate alternative. This process will raise (lower) the rate in the low (high) rate market.

Engle and Granger (1987) show that if a linear combination of non-stationary time series is stationary, the time series is co-integrated. If two time series are integrated of order one, the time series resulting from adding the two is integrated of order one. If $y_{t} \sim \mathrm{I}(1)$ and $x_{t} \sim \mathrm{I}(1)$, then $\left(y_{t}+x_{t}\right) \sim \mathrm{I}(1)$. However, if a beta, $\beta$, exits such that $\left(y_{t}\right.$ - $\left.\beta \mathrm{x}_{\mathrm{t}}\right) \sim \mathrm{I}(0)$, then $\mathrm{y}_{\mathrm{t}}$ and $\mathrm{x}_{\mathrm{t}}$ are said to be co-integrated. This co-integration equation reflects the long-term relationship between $\mathrm{y}_{\mathrm{t}}$ and $\mathrm{x}_{\mathrm{t}}$.

If we can construct a linear combination of $y_{t}$ and $x_{t}$ such that the difference of the two variables has a unit root, the two variables are co-integrated and the regression coefficient is the co-integration parameter.

$\mathrm{y}_{\mathrm{t}}=\beta_{0}+\beta_{1} \mathrm{x}_{\mathrm{t}}+\mathrm{u}_{\mathrm{t}}$

If $\mathrm{u}_{\mathrm{t}}$ is $\mathrm{I}(0)$, then $\mathrm{y}_{\mathrm{t}}$ and $\mathrm{x}_{\mathrm{t}}$ are co-integrated. The model for testing for co-integration with a time trend includes a time variable.

$y_{t}=\beta_{0}+\beta_{2}(t)+\beta_{1} x_{t}+u_{t}$

If $\mathrm{u}_{\mathrm{t}}$ is $\mathrm{I}(0)$, then $\mathrm{y}_{\mathrm{t}}$ and $\mathrm{x}_{\mathrm{t}}$ are co-integrated.

\section{ERROR CORRECTION MODELS}

Error correction models are a class of models that provide insight into the long-term relationship between variables in terms of the "impact propensity, long run propensity, and lag distribution for $\Delta y$ as a distributed lag in $\Delta \mathrm{x} .{ }^{2}$ The independent variable is $\mathrm{x}$ and the dependent variable is $\mathrm{y}$. An error correction term is computed based on the past values of both $\mathrm{x}$ and $\mathrm{y}$. If past values of $\mathrm{y}$ are over-estimated, future values will be moved back toward

\footnotetext{
${ }^{2}$ Wooldridge (2003), page 621.
} 
equilibrium by the error correction factor. In the example of the six-month and three-month Treasury bill rates, the error correction term is computed from the difference of the one period lagged six-month rate and the two-period lagged three-month rate. Thus, if either of the two rates drift too far from the long-term rate, the error correction term shows the tendency of the rates to return to the long-term rate.

If two variables are cointegrated, we can construct a variable, $s_{t}$, which is $I(0)$. The resulting error correction equation is

$\Delta \mathrm{x}_{\mathrm{t}}=\alpha^{*}+\beta^{*} \mathrm{x}_{\mathrm{t}-1}+\gamma^{*} \mathrm{y}_{\mathrm{t}}+\gamma^{*} \mathrm{y}_{\mathrm{t}-1}+\delta^{*} \mathrm{~s}_{\mathrm{t}-1}+\varepsilon_{\mathrm{t}}^{*}$

where, $\mathrm{s}_{\mathrm{t}-1}$, equals $\left(\mathrm{y}_{\mathrm{t}-1}-\beta^{*} \mathrm{x}_{\mathrm{t}-1}\right)$ and is the error correction term.

We can analyze the short-term effects of the relationship between the two variables. If the value of $\delta<0$, the error correction term serves to return the process to the long-run value. That is, if $\left(\mathrm{y}_{\mathrm{t}-1}>\beta^{*} \mathrm{x}_{\mathrm{t}-1}\right)$, the process was above the long-run value in the previous period and has been moved back by the error correction process.

\section{GENERATING THE SIMULATED DATA}

We use an Excel spreadsheet and the Excel function Rand() to generate four times series of numbers of 1,000 observations each. Rand() generates a number from zero to one. In order to create a random number series with a value of zero, the random number generated by Rand() is transformed into a zero value function by subtracting 0.50 from each $\operatorname{Rand}()$ value, $\operatorname{Rand}(*)=(\operatorname{Rand}()-0.50)$. This random number generated by $\operatorname{Rand}()$ and transformed to a zero value number is used to create an Index value with the following equation:

$\operatorname{Index}(\mathrm{i}, \mathrm{t})=\operatorname{Index}(\mathrm{i}, \mathrm{t}-1)(1+\operatorname{Rand}()($ Return $)+$ Trend $)$

$\operatorname{Index}(\mathrm{i}, \mathrm{t})=\operatorname{Index}(\mathrm{i}, \mathrm{t}-1)=1.0000(1+0.0025+.005)$

Index $(i, t)$ is the index value for each period " $t$ " that is calculated from the previous Index $(i, t)$ value plus a randomly generated value with an expected value of zero plus the trend. The trend is a long-run trend added to the random index change in order to create both a random component of the Index plus a trend. Four Indexes are generated using this function with 1001 observations each.

Returns are calculated from each Index $(i, t)$ using the natural logarithm function. Return(i,t) is the natural logarithm of the ratio of $\operatorname{Index}(\mathrm{i}, \mathrm{t})$ divided by $\operatorname{Index}(\mathrm{i}, \mathrm{t}-1)$.

$\operatorname{Return}(\mathrm{i}, \mathrm{t})=(\operatorname{Index}(\mathrm{i}, \mathrm{t})) /(\operatorname{Index}(\mathrm{i}, \mathrm{t}-1))$

Each return series has 1,000 observations that have both a random component and a trend component. The random component is the value of $\operatorname{Rand}(*)(\operatorname{Return})$ that is added to each previous Index $(\mathrm{i}, \mathrm{t})$ plus a trend.

\section{ANALYSIS OF THE GENERATED RETURNS}

The four return series are analyzed using EViews. Figures 1 to 5 show the probability distribution for each of the four return series. Figure 1 shows the sample statistics and analysis for Return $(1, t)$ which has a mean value of 0.04981 with a standard deviation of 0.005108 . The skewness statistic equals -0.022106 and the kurtosis statistic equals 2.8937. The Jarque-Bera statistic to measure normality is 0.55 , indicating that the probability distribution for the Return $(1, \mathrm{t})$ is normal. All four Return $(\mathrm{I}, \mathrm{t})$ series have expected values and standard deviations that are similar and Jarque-Bera statistics that do not reject normality. That is, all four Return(i,t) series exhibit the probability distribution statistics that one would expect given the method used to construct each of the four Return(I,t) series. 


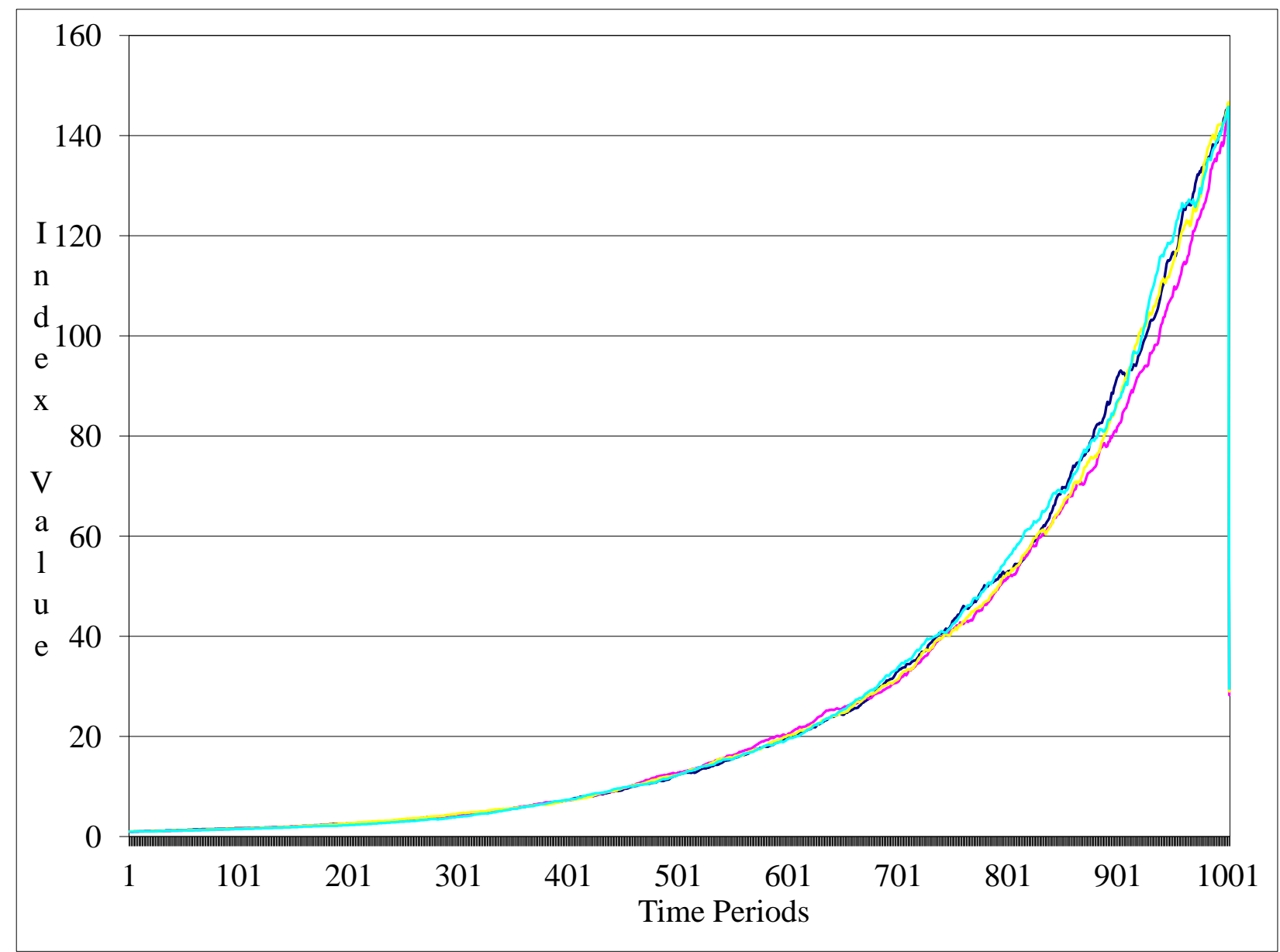

Figure 1: Graph of Four Indexes Time Series Analysis Simulation

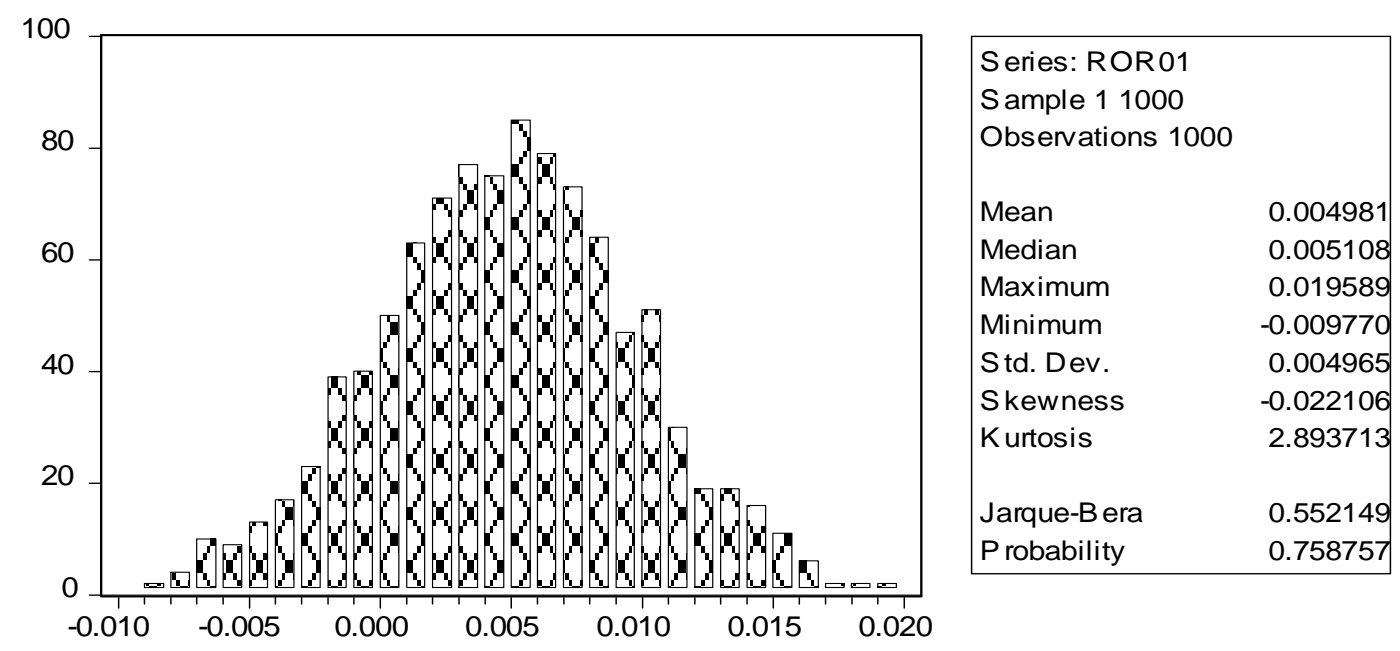

Figure 2: Summary Statistics for ROR01

Time Series Analysis Simulation 


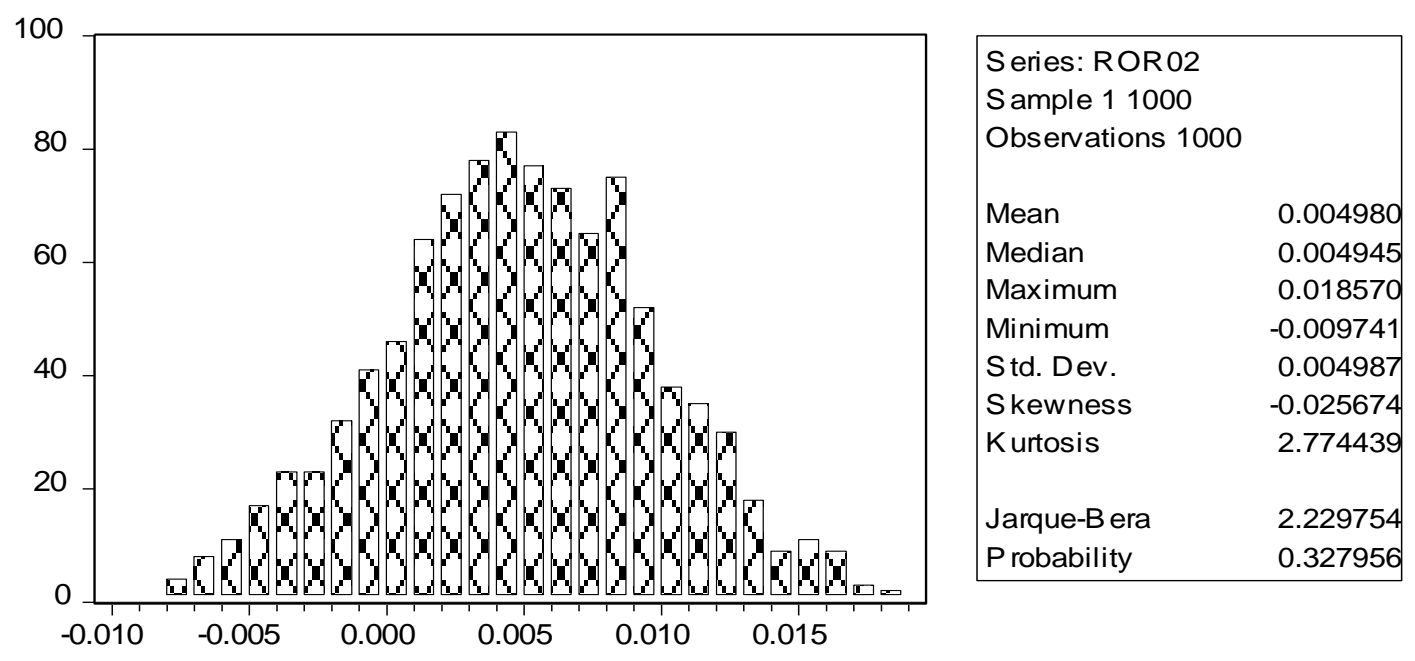

Figure 3: Summary Statistics for ROR02

Time Series Analysis Simulation

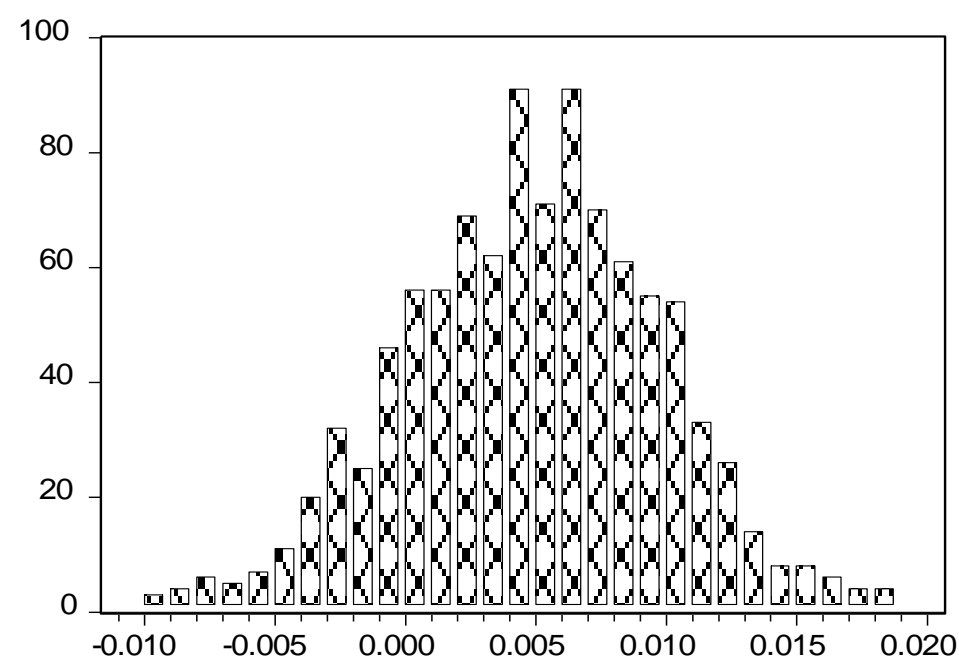

\begin{tabular}{|lr|}
\hline S eries: ROR03 & \\
Sample 1 1000 & \\
Observations 1000 & \\
& \\
Mean & 0.004978 \\
Median & 0.005077 \\
Maximum & 0.019341 \\
Minimum & -0.010689 \\
Std. Dev. & 0.004985 \\
Skewness & -0.117149 \\
Kurtosis & 3.031226 \\
& \\
Jarque-B era & 2.327943 \\
Probability & 0.312244 \\
\hline
\end{tabular}

Figure 4: Summary Statistics for ROR04

Time Series Analysis Simulation 


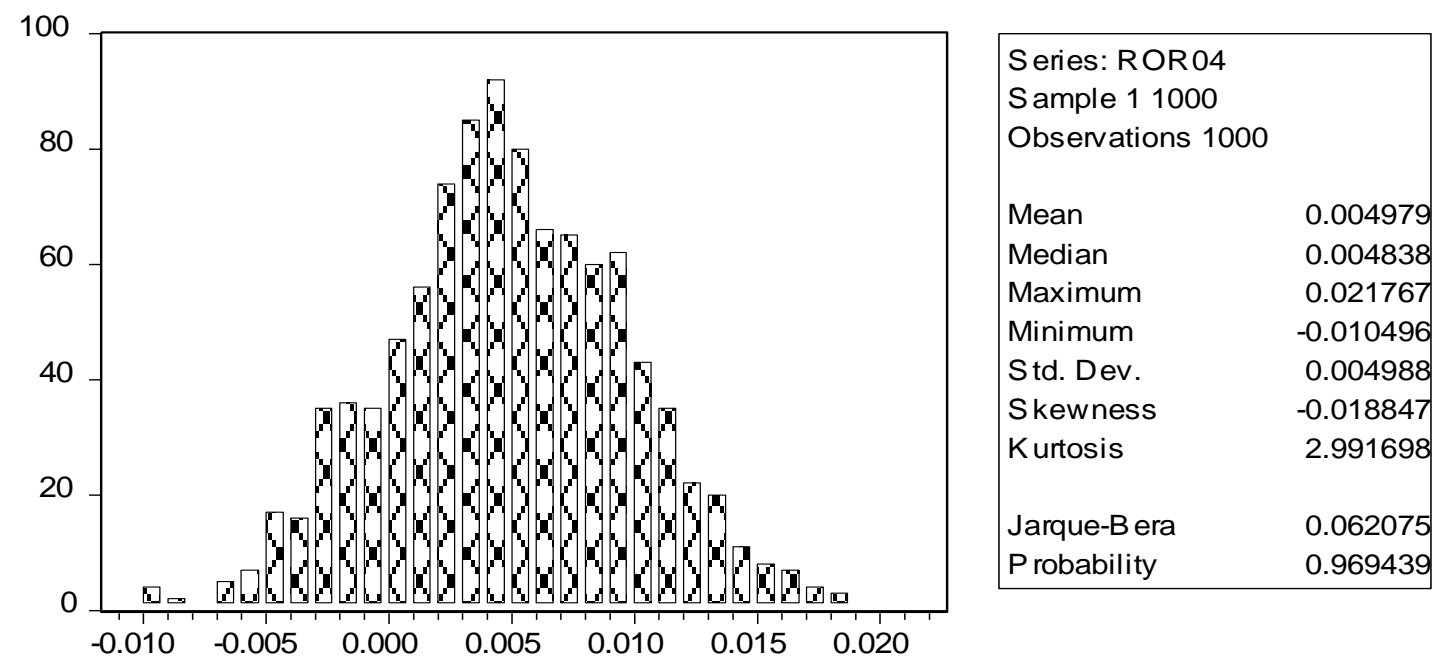

Figure 5: Summary Statistics for ROR04

Time Series Analysis Simulation

Table 2 contains the correlation matrix for the four Return(i,t) series. The four Return(i,t) series are constructed with a short-run random component and a long-run trend component. The correlation coefficients for the four Return(i,t) series reflect the short-run relationship between each of the Return(i,t) series. Thus, we see in Table 1 that the correlation coefficients for the four Return(i,t) series are all low and none are statistically significant.

Table 1: Summary Statistics

Time Series Analysis Simulation

\begin{tabular}{|l|c|c|c|c|}
\hline & ROR01 & ROR02 & ROR03 & ROR04 \\
\hline Mean & 0.004981 & 0.004980 & 0.004978 & 0.004979 \\
\hline Median & 0.005108 & 0.004945 & 0.005077 & 0.004838 \\
\hline Maximum & 0.019589 & 0.018570 & 0.019341 & 0.021767 \\
\hline Minimum & -0.009770 & -0.009741 & -0.010689 & -0.010496 \\
\hline Std. Dev. & 0.004965 & 0.004987 & 0.004985 & 0.004988 \\
\hline Skewness & -0.022106 & -0.025674 & -0.117149 & -0.018847 \\
\hline Kurtosis & 2.893713 & 2.774439 & 3.031226 & 2.991698 \\
\hline & & & & \\
\hline Jarque-Bera & 0.552149 & 2.229754 & 2.327943 & 0.062075 \\
\hline Probability & 0.758757 & 0.327956 & 0.312244 & 0.969439 \\
\hline & & & & \\
\hline Observations & 1000 & 1000 & & \\
\hline
\end{tabular}

Table 2: Correlation Matrix

Time Series Analysis Simulation

\begin{tabular}{|c|c|c|c|}
\hline ROR01 & ROR02 & ROR03 & ROR04 \\
\hline 1.000000 & -0.040348 & 0.001985 & 0.034449 \\
\hline-0.040348 & 1.000000 & 0.023084 & -0.039111 \\
\hline 0.001985 & 0.023084 & 1.000000 & 0.031080 \\
\hline 0.034449 & -0.039111 & 0.031080 & 1.000000 \\
\hline
\end{tabular}


Generally, the first step in analyzing the relationships between time series is to determine if each Return(i,t) series has a unit root. The Augmented Dickey-Fuller test for a unit root is performed for each of the four Return(i,t) series and the empirical results are detailed in Table 3, Table 4, Table 5, and Table 6 for each simulated return series. For the Return $(1, t)$ series, the ADF test statistic is -14.63 and the critical value for the ADF test statistic is 3.97 which indicates that Return $(1, t)$ series does not have a unit root. None of the four lagged Return $(1, t)$ series variable regression coefficients are statistically significant, but the intercept term is and equals 0.5014 . The adjusted $\mathrm{R}^{2}$ for the regression is 0.4798 and the F-statistic is 152 . These results reject the presence of a unit root. That is, Return( $1, \mathrm{t})$ series does not have a unit root which is consistent with the method of creating the Return(i,t) series. The results for all four Return(i,t) series are similar to the results for Return(1,t) series.

Table 3: Unit Root Analysis

Time Series Analysis Simulation (ROR01)

\begin{tabular}{|l|l|l|l|}
\hline ADF Test Statistic & -14.64202 & $1 \%$ Critical Value* & -3.4397 \\
\hline & & $5 \%$ Critical Value & -2.8649 \\
\hline & & $10 \%$ Critical Value & -2.5685 \\
\hline
\end{tabular}

*MacKinnon critical values for rejection of hypothesis of a unit root.

\begin{tabular}{|l|l|l|l|l|}
\hline & & & & \\
\hline & & & & \\
\hline
\end{tabular}

Augmented Dickey-Fuller Test Equation

Dependent Variable: D(ROR01)

Method: Least Squares

Date: 11/05/08 Time: 17:44

Sample(adjusted): 61000

Included observations: 995 after adjusting endpoints

\begin{tabular}{|c|c|c|c|c|}
\hline Variable & Coefficient & Std. Error & t-Statistic & Prob. \\
\hline ROR01(-1) & -1.009307 & 0.068932 & -14.64202 & 0.0000 \\
\hline D(ROR01(-1)) & 0.050457 & 0.061538 & 0.819932 & 0.4125 \\
\hline D(ROR01(-2)) & 0.052299 & 0.053490 & 0.977737 & 0.3284 \\
\hline D(ROR01(-3)) & 0.050287 & 0.044008 & 1.142698 & 0.2534 \\
\hline D(ROR01(-4)) C & 0.032641 & 0.031805 & 1.026271 & 0.3050 \\
\hline R-squared & 0.005031 & 0.000378 & 13.31435 & 0.0000 \\
\hline Adjusted R-squared & 0.479762 & Mean dependent var & $4.66 \mathrm{E}-06$ \\
\hline S.E. of regression & 0.477132 & S.D. dependent var & 0.006887 \\
\hline Sum squared resid & 0.004980 & Akaike info criterion & -7.760815 \\
\hline Log likelihood & 0.024526 & Schwarz criterion & -7.731251 \\
\hline Durbin-Watson stat & 3867.005 & F-statistic & 182.4109 \\
\hline
\end{tabular}


Table 4: Unit Root Analysis

Time Series Analysis Simulation (ROR02)

\begin{tabular}{|l|l|l|l|}
\hline ADF Test Statistic & -15.62956 & $1 \%$ Critical Value* & -3.4397 \\
\hline & & $5 \%$ Critical Value & -2.8649 \\
\hline & & $10 \%$ Critical Value & -2.5685 \\
\hline
\end{tabular}

*MacKinnon critical values for rejection of hypothesis of a unit root.

Augmented Dickey-Fuller Test Equation

Dependent Variable: D(ROR02)

Method: Least Squares

Date: 11/05/08 Time: 17:45

Sample(adjusted): 61000

Included observations: 995 after adjusting endpoints

\begin{tabular}{|c|c|c|c|c|}
\hline Variable & Coefficient & Std. Error & t-Statistic & Prob. \\
\hline ROR02(-1) & -1.122367 & 0.071811 & -15.62956 & 0.0000 \\
\hline D(ROR02(-1)) & 0.145336 & 0.063859 & 2.275887 & 0.0231 \\
\hline D(ROR02(-2)) & 0.144089 & 0.054330 & 2.652124 & 0.0081 \\
\hline D(ROR02(-3)) & 0.065803 & 0.044582 & 1.476016 & 0.1403 \\
\hline D(ROR02(-4)) & 0.078950 & 0.031802 & 2.482531 & 0.0132 \\
\hline C & 0.005613 & 0.000390 & 14.39128 & 0.0000 \\
\hline Adjusted R-squared & 0.496699 & Mean dependent var & $1.23 \mathrm{E}-05$ \\
\hline S.E. of regression & 0.494154 & S.D. dependent var & 0.006978 \\
\hline Sum squared resid & 0.004963 & Akaike info criterion & -7.767596 \\
\hline Log likelihood & 0.024361 & Schwarz criterion & -7.738032 \\
\hline Durbin-Watson stat & 3870.379 & F-statistic & 195.2052 \\
\hline
\end{tabular}

Table 5: Unit Root Analysis

Time Series Analysis Simulation (ROR03)

\begin{tabular}{|c|c|c|c|c|}
\hline \multirow[t]{3}{*}{ ADF Test Statistic } & -13.85796 & \multicolumn{2}{|c|}{$1 \%$ Critical Value* } & -3.4397 \\
\hline & & \multicolumn{2}{|c|}{$5 \%$ Critical Value } & -2.8649 \\
\hline & & \multicolumn{2}{|c|}{$10 \%$ Critical Value } & -2.5685 \\
\hline \multicolumn{5}{|c|}{ *MacKinnon critical values for rejection of hypothesis of a unit root. } \\
\hline & & & & \\
\hline \multicolumn{5}{|c|}{ Augmented Dickey-Fuller Test Equation } \\
\hline \multicolumn{5}{|c|}{ Dependent Variable: D(ROR03) } \\
\hline \multicolumn{5}{|c|}{ Method: Least Squares } \\
\hline \multicolumn{5}{|l|}{ Date: $11 / 05 / 08$ Time: $17: 46$} \\
\hline \multicolumn{5}{|c|}{ Sample(adjusted): 61000} \\
\hline \multicolumn{5}{|c|}{ Included observations: 995 after adjusting endpoints } \\
\hline Variable & Coefficient & Std. Error & t-Statistic & Prob. \\
\hline ROR03(-1) & -0.977154 & 0.070512 & -13.85796 & 0.0000 \\
\hline D(ROR03(-1)) & -0.030249 & 0.063229 & -0.478401 & 0.6325 \\
\hline D(ROR03(-2)) & -0.006233 & 0.054924 & -0.113485 & 0.9097 \\
\hline D(ROR03(-3)) & -0.007407 & 0.045141 & -0.164077 & 0.8697 \\
\hline $\mathrm{D}($ ROR03(-4)) & -0.003669 & 0.031785 & -0.115440 & 0.9081 \\
\hline $\mathrm{C}$ & 0.004858 & 0.000385 & 12.63444 & 0.0000 \\
\hline R-squared & 0.504057 & \multicolumn{2}{|c|}{ Mean dependent var } & $3.28 \mathrm{E}-06$ \\
\hline Adjusted R-squared & 0.501550 & \multicolumn{2}{|c|}{ S.D. dependent var } & 0.007089 \\
\hline S.E. of regression & 0.005005 & \multicolumn{2}{|c|}{ Akaike info criterion } & -7.750766 \\
\hline Sum squared resid & 0.024774 & \multicolumn{2}{|c|}{ Schwarz criterion } & -7.721202 \\
\hline Log likelihood & 3862.006 & \multicolumn{2}{|c|}{ F-statistic } & 201.0363 \\
\hline Durbin-Watson stat & 1.999506 & \multicolumn{2}{|c|}{ Prob(F-statistic) } & 0.000000 \\
\hline
\end{tabular}


Table 6: Unit Root Analysis

Time Series Analysis Simulation (ROR04)

\begin{tabular}{|l|l|l|r|}
\hline ADF Test Statistic & -14.21379 & $1 \%$ Critical Value* & -3.4397 \\
\hline & & $5 \%$ Critical Value & -2.8649 \\
\hline & & $10 \%$ Critical Value & -2.5685 \\
\hline
\end{tabular}

*MacKinnon critical values for rejection of hypothesis of a unit root.

\begin{tabular}{|l|l|l|l|l|}
\hline & & & & \\
\hline & & & & \\
\hline
\end{tabular}

Augmented Dickey-Fuller Test Equation

Dependent Variable: D(ROR04)

Method: Least Squares

Date: 11/05/08 Time: 17:47

Sample(adjusted): 61000

Included observations: 995 after adjusting endpoints

\begin{tabular}{|c|c|c|c|c|}
\hline Variable & Coefficient & Std. Error & t-Statistic & Prob. \\
\hline ROR04(-1) & -0.994839 & 0.069991 & -14.21379 & 0.0000 \\
\hline D(ROR04(-1)) & -0.016501 & 0.062820 & -0.262676 & 0.7929 \\
\hline D(ROR04(-2)) & 0.004275 & 0.054997 & 0.077740 & 0.9381 \\
\hline D(ROR04(-3)) & 0.037461 & 0.045140 & 0.829900 & 0.4068 \\
\hline D(ROR04(-4)) C & 0.022649 & 0.031757 & 0.713186 & 0.4759 \\
\hline R-squared & 0.004972 & 0.000383 & 12.96960 & 0.0000 \\
\hline Adjusted R-squared & 0.506667 & Mean dependent var & $3.63 \mathrm{E}-06$ \\
\hline S.E. of regression & 0.504173 & S.D. dependent var & 0.007100 \\
\hline Sum squared resid & 0.004999 & Akaike info criterion & -7.753052 \\
\hline Log likelihood & 0.024717 & Schwarz criterion & -7.723487 \\
\hline Durbin-Watson stat & 3863.143 & F-statistic & 203.1462 \\
\hline
\end{tabular}

The next step in the time-series analysis process is to determine if the four Return(i,t) series Granger cause each other. Table 7 shows the Granger causality statistics for the four Return(i,t) series. There are six combinations of Granger causality between the four Return(i,t) series, such as a determination if Return $(1, \mathrm{t})$ series Granger causes Return $(2, t)$ series and vice versa. In all six cases, Granger causality is rejected, as would be expected since the short-run component for each of the four Return(i,t) series are randomly generated.

Table 7: Granger Causality Tests

Time Series Analysis Simulation

Date: 11/05/08 Time: 17:48

Sample: 11000

Lags: 2

Null Hypothesis:

ROR02 does not Granger Cause ROR01

ROR01 does not Granger Cause ROR02

ROR03 does not Granger Cause ROR01

ROR01 does not Granger Cause ROR03

ROR04 does not Granger Cause ROR01

ROR01 does not Granger Cause ROR04

ROR03 does not Granger Cause ROR02

ROR02 does not Granger Cause ROR03

ROR04 does not Granger Cause ROR02

ROR02 does not Granger Cause ROR04

ROR04 does not Granger Cause ROR03

ROR03 does not Granger Cause ROR04

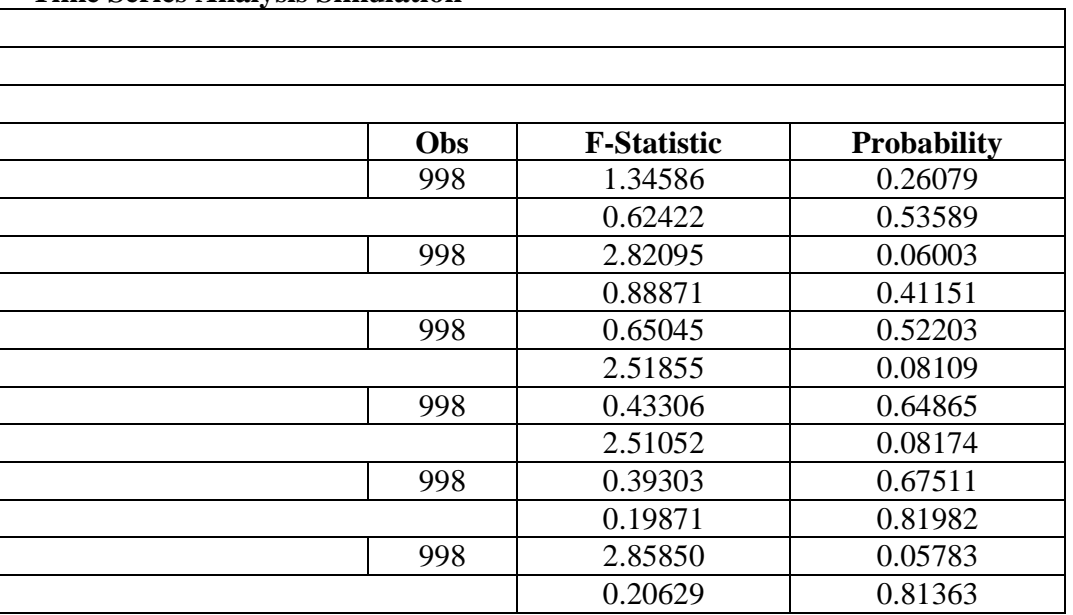


Once one has determined that the four Return(i,t) series are normally distributed with no statistically significant correlation, that the four Return(i,t) series are stationary with no unit roots, and that the four Return(i,t) series do not Granger cause each other, the four Return(i,t) series are tested for cointegration. Cointegration tests determine if the four Return(i,t) series have a long-run relationship that is not random as is the short-run relationship. Given that the four Return(i,t) series are constructed with an equal trend, we expect that the four Return(i,t) series will exhibit cointegration, which means that the four Return(i,t) series have a long-run relationship; i.e., the four Return(i,t) series follow the same long-run trend. Table 8 contains the results of the Johansen cointegration test. The test results indicate that there are four cointegrating equations at the $1 \%$ level of statistical significance as would be expected by the process by which in indices were constructed.

Table 8: Cointegration Tests

Time Series Analysis Simulation

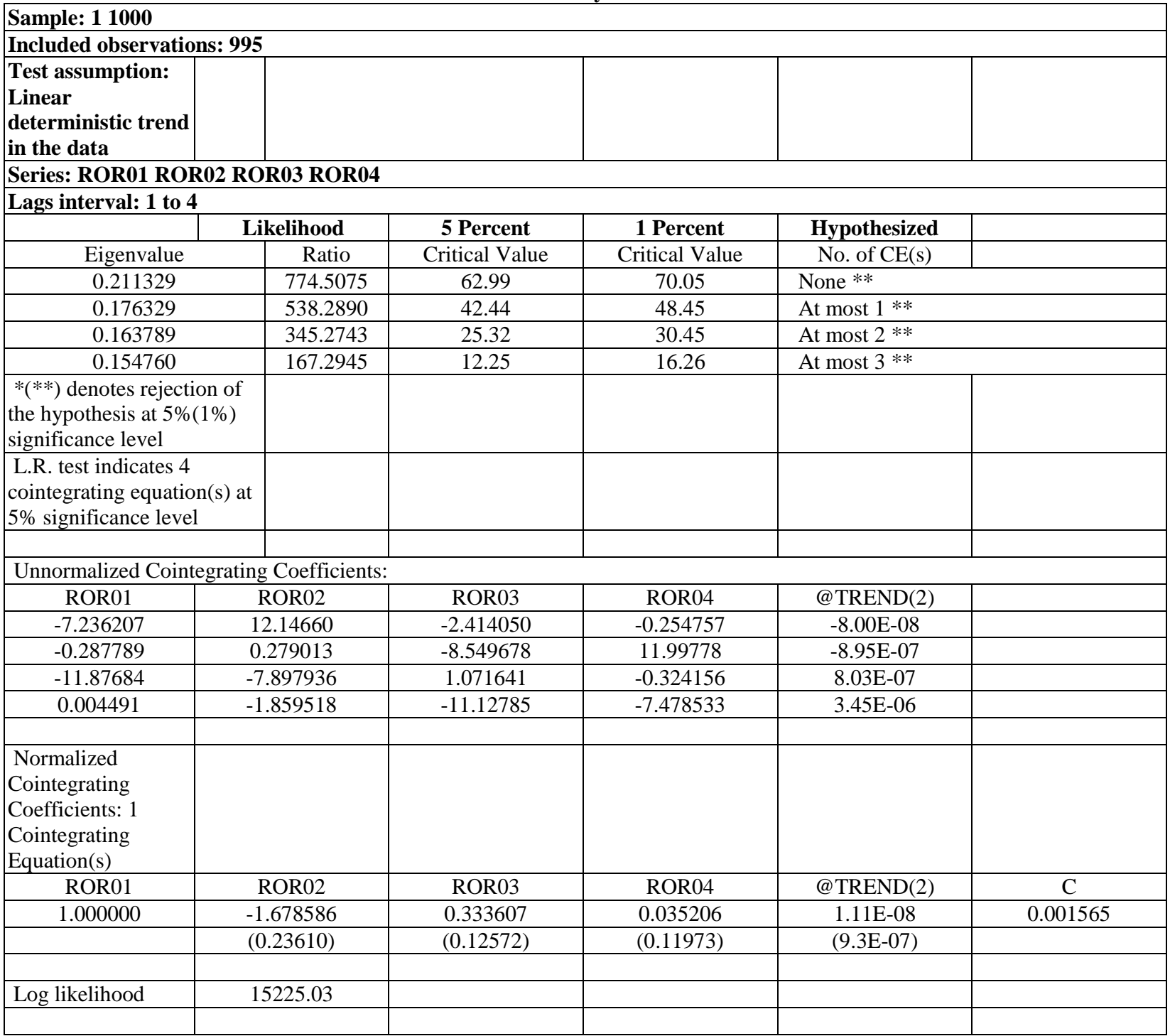


Table 8: Continued

\begin{tabular}{|c|c|c|c|c|c|}
\hline \multicolumn{6}{|l|}{$\begin{array}{l}\text { Normalized } \\
\text { Cointegrating } \\
\text { Coefficients: } 2 \\
\text { Cointegrating } \\
\text { Equation(s) }\end{array}$} \\
\hline ROR01 & ROR02 & ROR03 & ROR04 & @TREND(2) & $\mathrm{C}$ \\
\hline \multirow[t]{2}{*}{1.000000} & 0.000000 & 69.87104 & -98.73838 & $7.35 \mathrm{E}-06$ & 0.137262 \\
\hline & & $(653.897)$ & $(925.581)$ & $(9.3 \mathrm{E}-05)$ & \\
\hline \multirow[t]{2}{*}{0.000000} & 1.000000 & 41.42619 & -58.84332 & $4.37 \mathrm{E}-06$ & 0.080840 \\
\hline & & $(389.716)$ & $(551.637)$ & $(5.6 \mathrm{E}-05)$ & \\
\hline Log likelihood & 15321.54 & & & & \\
\hline \multicolumn{6}{|l|}{$\begin{array}{l}\text { Normalized } \\
\text { Cointegrating } \\
\text { Coefficients: } 3 \\
\text { Cointegrating } \\
\text { Equation(s) }\end{array}$} \\
\hline ROR01 & ROR02 & ROR03 & ROR04 & @ TREND(2) & $\mathrm{C}$ \\
\hline \multirow[t]{2}{*}{1.000000} & 0.000000 & 0.000000 & 0.072012 & $-4.85 \mathrm{E}-08$ & -0.005315 \\
\hline & & & $(0.11737)$ & $(5.5 \mathrm{E}-07)$ & \\
\hline \multirow[t]{2}{*}{0.000000} & 1.000000 & 0.000000 & -0.259132 & $-1.44 \mathrm{E}-08$ & -0.003693 \\
\hline & & & $(0.11115)$ & $(5.2 \mathrm{E}-07)$ & \\
\hline \multirow[t]{2}{*}{0.000000} & 0.000000 & 1.000000 & -1.414182 & $1.06 \mathrm{E}-07$ & 0.002041 \\
\hline & & & $(0.19130)$ & (8.9E-07) & \\
\hline Log likelihood & 15410.53 & & & & \\
\hline
\end{tabular}

Table 9 contains the empirical results for the VEC model with an intercept and with an intercept but no trend in the error correction model. This empirical results for this model show that the error correction equation is not statistically significant except in one case, ROR01 and ROR03(-2). The error correction variables are mostly not statistically significant and the signs are random. The adjusted $\mathrm{R}^{2}$ for the models are 0.003339 or less and the $\mathrm{F}$ statistics are not statistically significant. Table 10 contains the empirical results for the VEC model with a trend in the data and both an intercept and a trend in the error correction model. Given that the four Return(i,t) series are constructed with an intercept and a trend, the model with a trend in the data and a VEC model with both an intercept and a trend would seem to be most appropriate. This empirical results for this model show that the error correction equation is statistically significant but the trend is not statistically significant because the regression model accounts for the long-run trend effect across the four Return(i,t) series. Although the error correction variables are mostly statistically significant, the signs are random. This supports the hypothesis that cointegration is statistically significant but random in effect. The adjusted $\mathrm{R}^{2}$ for the models are 0.33 or greater and the F-statistics are not statistically significant. 
Table 9: Vector Error Correction Regression Time Series Analysis Simulation

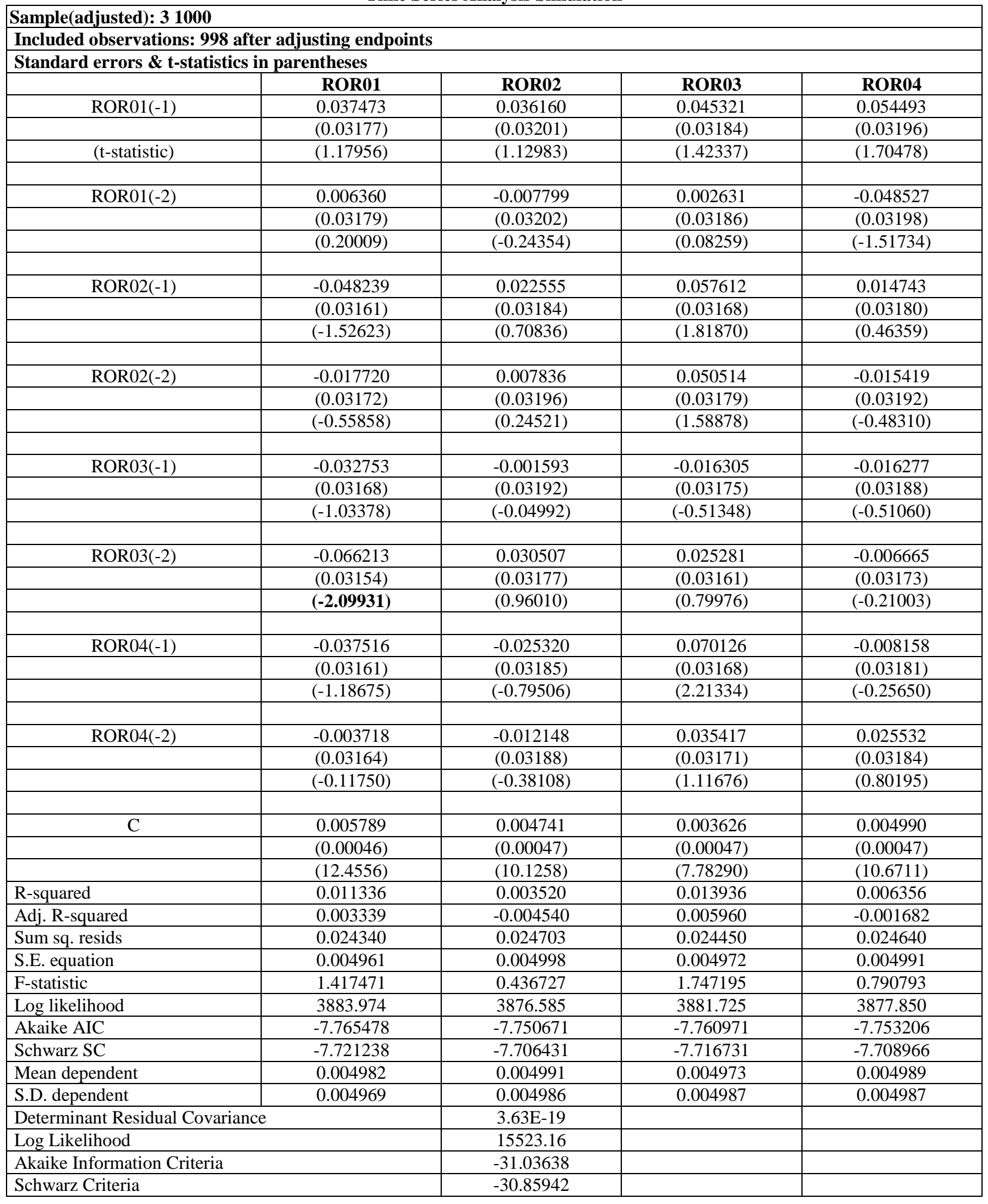


Table 10: VEC Regression

Time Series Analysis Simulation

\begin{tabular}{|c|c|c|c|c|}
\hline \multicolumn{5}{|c|}{ Date: 11/05/08 Time: 17:52 } \\
\hline \multicolumn{5}{|c|}{ Sample(adjusted): 41000} \\
\hline \multicolumn{5}{|c|}{ Included observations: 997 after adjusting endpoints } \\
\hline \multicolumn{5}{|c|}{ Standard errors \& t-statistics in parentheses } \\
\hline Cointegrating Eq: & CointEq1 & & & \\
\hline ROR01(-1) & 1.000000 & & & \\
\hline \multirow[t]{3}{*}{ ROR02(-1) } & -3.107689 & & & \\
\hline & $(0.56475)$ & & & \\
\hline & $(-5.50280)$ & & & \\
\hline & & & & \\
\hline \multirow[t]{3}{*}{ ROR03(-1) } & 0.912382 & & & \\
\hline & $(0.23212)$ & & & \\
\hline & $(3.93063)$ & & & \\
\hline & & & & \\
\hline \multirow[t]{3}{*}{ ROR04(-1) } & -0.294429 & & & \\
\hline & $(0.18021)$ & & & \\
\hline & $(-1.63381)$ & & & \\
\hline & & & & \\
\hline \multirow[t]{3}{*}{$@$ TREND(1) } & $2.80 \mathrm{E}-07$ & & & \\
\hline & $(1.7 \mathrm{E}-06)$ & & & \\
\hline & $(0.16173)$ & & & \\
\hline & & & & \\
\hline $\mathrm{C}$ & 0.007315 & & & \\
\hline Error Correction: & D(ROR01) & D(ROR02) & D(ROR03) & D(ROR04) \\
\hline \multirow[t]{3}{*}{ CointEq1 } & -0.103659 & 0.292230 & -0.065245 & -0.004799 \\
\hline & $(0.01815)$ & $(0.01644)$ & $(0.01838)$ & $(0.01839)$ \\
\hline & $(-5.71090)$ & $(17.7705)$ & $(-3.55066)$ & $(-0.26097)$ \\
\hline \multirow[t]{3}{*}{ D(ROR01(-1)) } & -0.564791 & -0.168134 & 0.096734 & 0.085316 \\
\hline & $(0.03221)$ & $(0.02918)$ & $(0.03261)$ & $(0.03263)$ \\
\hline & $(-17.5362)$ & $(-5.76207)$ & $(2.96677)$ & $(2.61473)$ \\
\hline \multirow[t]{3}{*}{ D(ROR01(-2)) } & -0.281775 & -0.104444 & 0.048403 & 0.043913 \\
\hline & $(0.03050)$ & $(0.02763)$ & $(0.03088)$ & $(0.03090)$ \\
\hline & $(-9.23802)$ & $(-3.77949)$ & $(1.56749)$ & $(1.42106)$ \\
\hline \multirow[t]{3}{*}{ D(ROR02(-1)) } & -0.271974 & -0.024072 & -0.085798 & 0.011477 \\
\hline & $(0.04767)$ & $(0.04319)$ & $(0.04826)$ & $(0.04829)$ \\
\hline & $(-5.70549)$ & $(-0.55737)$ & $(-1.77788)$ & $(0.23765)$ \\
\hline \multirow{3}{*}{ D(ROR02(-2)) } & -0.181455 & 0.029367 & 0.016240 & 0.004272 \\
\hline & $(0.03492)$ & $(0.03164)$ & $(0.03536)$ & $(0.03538)$ \\
\hline & $(-5.19561)$ & $(0.92813)$ & $(0.45932)$ & $(0.12075)$ \\
\hline \multirow[t]{3}{*}{ D(ROR03(-1)) } & 0.045638 & -0.193440 & -0.647836 & -0.023562 \\
\hline & $(0.03128)$ & $(0.02834)$ & $(0.03167)$ & $(0.03169)$ \\
\hline & $(1.45908)$ & $(-6.82615)$ & $(-20.4587)$ & $(-0.74355)$ \\
\hline \multirow[t]{3}{*}{ D(ROR03(-2)) } & -0.016325 & -0.079441 & -0.303542 & -0.023596 \\
\hline & $(0.02986)$ & $(0.02705)$ & $(0.03023)$ & $(0.03025)$ \\
\hline & $(-0.54669)$ & $(-2.93644)$ & $(-10.0410)$ & $(-0.77997)$ \\
\hline
\end{tabular}


Table 10: Continued

\begin{tabular}{|l|c|c|c|c|}
\hline \multicolumn{1}{|c|}{ D(ROR04(-1)) } & -0.039442 & 0.050380 & 0.031532 & -0.699384 \\
\hline & $(0.02978)$ & $(0.02698)$ & $(0.03015)$ & $(0.03017)$ \\
\hline & $(-1.32425)$ & $(1.86700)$ & $(1.04573)$ & $(-23.1778)$ \\
\hline D(ROR04(-2)) & & & & -0.347010 \\
\hline & -0.017275 & 0.019816 & 0.028660 & $(0.02989)$ \\
\hline \multicolumn{1}{|c|}{ C } & $(0.02951)$ & $(0.02673)$ & $(0.02987)$ & $(-11.6084)$ \\
\hline & $(-0.58546)$ & $(0.74127)$ & $(0.95945)$ & $1.04 \mathrm{E}-05$ \\
\hline & & & & $(0.00018)$ \\
\hline & $1.15 \mathrm{E}-05$ & $8.67 \mathrm{E}-06$ & $(0.00018)$ & $(0.05745)$ \\
\hline R-squared & $(0.00018)$ & $(0.00016)$ & $(0.00809)$ & 0.360589 \\
\hline Adj. R-squared & $(0.06462)$ & $(0.05373)$ & 0.359639 & 0.354758 \\
\hline Sum sq. resids & 0.338356 & 0.471541 & 0.353800 & 0.032037 \\
\hline S.E. equation & 0.332323 & 0.466723 & 0.031991 & 0.005697 \\
\hline F-statistic & 0.031214 & 0.025621 & 0.005693 & 61.84533 \\
\hline Log likelihood & 0.005624 & 0.005095 & 61.59097 & 3742.601 \\
\hline Akaike AIC & 56.08207 & 97.85510 & 3743.319 & -7.487665 \\
\hline Schwarz SC & 3755.577 & 3854.005 & -7.489105 & -7.438470 \\
\hline Mean dependent & -7.513695 & -7.711144 & -7.439910 & $4.64 \mathrm{E}-06$ \\
\hline S.D. dependent & -7.464500 & -7.661949 & $3.63 \mathrm{E}-07$ & 0.007093 \\
\hline Determinant Residual Covariance & $5.45 \mathrm{E}-06$ & $9.04 \mathrm{E}-06$ & & \\
\hline Log Likelihood & 0.006882 & 0.006977 & & \\
\hline Akaike Information Criteria & & $8.18 \mathrm{E}-19$ & & \\
\hline Schwarz Criteria & & 15102.52 & & \\
\hline
\end{tabular}

\section{THE VECTOR ERROR CORRECTION MODEL}

Vector AutoRegression technique cannot be applied to the four Return(i,t) series because the four Return(i,t) series are cointegrated; that is, the four Return(i,t) series follow the same long-run trend, but the short-run trend is random. There are eight options for running the VEC model. The VEC model can be run with no trend in the VEC but with an intercept included or not. The VEC model can be run with a trend in the VEC and an intercept and/or a trend in the cointegration equation. The vector error correction equation uses lagged deviations for each of the four Return(i,t) series as independent variables for each of the four Return(i,t) series in a regression that also include lagged deviation variables for each of the four Return(i,t) series. Each set of VEC estimated regression includes the cointegrating equation plus a series of deviations from past changes in the four Return(i,t) series with up to two lags, unless more lags are specified. In addition, each VEC analysis can include a trend in the VEC and/or an intercept or a trend for each VEC. Table 10 contains the empirical results for the VEC model with a trend in the data and both an intercept and a trend in the error correction model. Given that the four Return(i,t) series are constructed with an intercept and a trend, the model with a trend in the data and a VEC model with both an intercept and a trend would seem to be most appropriate. The empirical results for this model show that the error correction equation is statistically significant but the trend is not statistically significant because the regression model accounts for the long-run trend effect across the four Return(i,t) series. Although the error correction variables are mostly statistically significant, the signs are random. This supports the hypothesis that cointegration is statistically significant but random in effect. The other three models provide similar results.

\section{SUMMARY AND CONCLUSIONS}

In this paper, we generated four Return(i,t) series using Excel that have both a random component and a trend component for each of the four Return(i,t) series. We applied a series of tests for time series analysis correlation, normality, unit root, Granger causality, cointegration, and vector error correction regressions.

The empirical results are consistent with the method used to create the four Return(i,t) series. Each of the four Return(i,t) series has the same expected value and standard deviation, a low correlation with the other 
Return(i,t) series, which reflects the short-run random effect built into the four Return(i,t) series, no unit roots, and cointegration between the four Return(i,t) series, which Return(i,t) series is consistent with the method of constructing the four with a trend. Since the four Return(i,t) series are cointegrated by construction, a vector error correction model is appropriate for analysis of the long-run relationship between each of the four Return(i,t) series. The coinetegration equation is statistically significant as are the error correction variables, but in a random fashion with some of the regression coefficients being positive and some being negative.

In this paper, we show how to use the time series paradigm currently being used to conduct time series analysis. The basis of this analysis is the work in time series analysis done by noble laureate Engle and Granger. We demonstrate each of the steps designed to allow the researcher to determine if a relationship exists between two time series and to define the nature of that relationship.

\section{AUTHOR INFORMATION}

Carl B. McGowan, Jr., PhD, CFA is a Faculty Distinguished Professor and Professor of Finance at Norfolk State University, has a BA in International Relations (Syracuse), an MBA in Finance (Eastern Michigan), and a PhD in Business Administration (Finance) from Michigan State. From 2003 to 2004, he held the RHB Bank Distinguished Chair in Finance at the Universiti Kebangsaan Malaysia and has taught in Cost Rica, Malaysia, Moscow, Saudi Arabia, and The UAE. Professor McGowan has published in numerous journals including American Journal of Business Education, Applied Financial Economics, Decision Science, Financial Practice and Education, The Financial Review, International Business and Economics Research Journal, The International Review of Financial Analysis, The Journal of Applied Business Research, The Journal of Business Case Studies, The Journal of Diversity Management, The Journal of Real Estate Research, Managerial Finance, Managing Global Transitions, The Southwestern Economic Review, and Urban Studies. E-mail: cbmcgowan@nsu.edu. Corresponding author.

Izani Ibrahim, $\mathrm{PhD}$, is a Professor of Econometrics and Corporate Finance at the Graduate School of Business, National University of Malaysia. He received his B.Sc. (Actuarial Science) in 1985, from Pennsylvania State University, USA, and both his M.Sc. (Actuarial Science), in 1992 and Ph.D. (Finance), in 1996 from University of Nebraska, USA. Professor Izani has been giving lectures in quantitative methods at graduate level and to public and private sectors especially in Multivariate Analysis and Econometrics. His research interest in the finance area includes topics on corporate finance, derivatives and investment. Professor Izani has published in Capital Market Review, International Business \& Economics Research Journal, International Research Journal, Journal of Current Research in Global Business, Journal of International Trade and Economic Development, Journal Analisis, and Journal Pengurusan. E-mail: izani@ukm.my

\section{REFERENCES}

1. Dickey, D.A. and W.A. Fuller (1979) "Distribution of the Estimators for Autoregressive Time Series with a Unit Root," Journal of the American Statistical Association, 74, 427-431.

2. Engle, Robert F. and C.W.J. Granger (1987) "Co-integration and Error Correction: Representation, Estimation, and Testing," Econometrica 55, 251-276.

3. Jarque, C. and A. Bera (1980) "Efficient Tests for Normality, Homoskedasticity, and Serial Independence of Regression Residuals," Economics Letters, 6, 255-259.

4. Johansen, Soren (1991) "Estimation and Hypothesis Testing of Cointegration Vectors in Gaussian Vector Autoregressive Models," Econometrica, 59, 1551-1580.

5. Johansen, Soren and Katarina Juselius (1990) "Maximum Likelihood Estimation and Inferences on Cointegration - with applications to the demand for money," Oxford Bulletin of Economics and Statistics, $52,169-210$.

6. Wooldridge, Jeffrey M. Introductory Econometrics: A Modern Approach, Second Edition, Thomson South-Western, Mason, OH, 2003. 
NOTES 